\title{
Simvastatin intolerance genetic determinants: some features in ethnic Uzbek patients with coronary artery disease
}

Aleksandr B. Shek, Ravshanbek D. Kurbanov, Guzal J. Abdullaeva, Aleksandr V. Nagay,

Shavkat U. Hoshimov, Ulugbek I. Nizamov, Adolat V. Ziyaeva, Rano B. Alieva

Republican Specialised Centre of Cardiology, Tashkent, Uzbekistan

Submitted: 25 June 2017

Accepted: 3 September 2017

Arch Med Sci Atheroscler Dis 2017; 2: e68-e75

DOI: https://doi.org/10.5114/amsad.2017.70597

Copyright (c) 2017 Termedia \& Banach

\section{Abstract}

Introduction: The objective is to study the influence of CYP3A5 (6986A>G), CYP2C9 $(430 \mathrm{C}>\mathrm{T}), \mathrm{CYP} 2 \mathrm{C9}(1075 \mathrm{~A}>\mathrm{C}), \mathrm{SLCO1B} 1$ (521T>C) and BCRP (ABCG2, $421 C>A)$ gene polymorphisms on the development of simvastatin intolerance in ethnic Uzbek patients with coronary artery disease (CAD).

Material and methods: The case group contained 50 patients with clinical simvastatin-induced intolerance symptoms; the control group contained 50 patients without side-effects. Genotyping was performed by means of the PCR-RFLP method.

Results: Among 37 patients with simvastatin-induced liver symptoms the $* 3{ }^{*} 3$ genotype of the CYP3A5 gene $(p=0.0001)$ and variant genotype of the CA BCRP gene were observed more frequently than in the control group $(p=0.0001)$. However, when the 13 patients who had statin-associated muscle symptoms (SAMS) were compared with the control group $(n=50)$, it was found that in the case group the $3^{*} / 3^{*}$ genotype of the CYP3A5 gene $(\mathrm{OR}=8.6 ; 95 \% \mathrm{Cl}: 2.1-34.1 ; p=0.003)$ and $\mathrm{C}$ allele carriers of the gene polymorphism SLCO1B1 (OR $\left.=3.54 ; 95 \% \mathrm{Cl}: 1.35-9.27 ; \chi^{2}=5.7 ; p=0.017\right)$ were predominant.

Conclusions: The ${ }^{*} 3 /{ }^{*} 3$ genotype of the CYP3A5 (6986A>G) gene and CA genotype of the BCRP (ABCG2, 421C>A) gene were associated with simvastatin-induced liver symptoms in ethnic Uzbek CAD patients, whereas in patients with simvastatin-associated muscle symptoms (SAMS), the combination of ${ }^{*} 3{ }^{*} 3$ genotype of CYP3A5 (6986A $\left.>\mathrm{G}\right)$ and carriage of the $C$ allele of the SLCO1B1 gene polymorphism was predominant.

Key words: statin intolerance, genetic determinants, ethnic features.

\section{Introduction}

Statin treatment is a cornerstone of cardiovascular disease prevention and treatment, and application of statins in the majority of cases is safe and well tolerated [1]. More than 20 years of clinical studies have demonstrated that statins can prevent cardiovascular mortality, major cardiovascular events (complications such as stroke, myocardial infarction), as well as all-cause mortality [2, 3]. Certain success achieved worldwide in cardiovascular disease incidence reduction can be also related to the statin-associated cholesterol level lowering effect [4].

\author{
Corresponding author: \\ Prof. Aleksandr B. Shek \\ Republican Specialised \\ Centre of Cardiology \\ 4 , Osyo \\ 47,35, Mirobod St \\ 100052 Tashkent, \\ Uzbekistan \\ Phone: +998712525455 \\ Fax: +998712341667 \\ E-mail: shek-999@mail.ru
}


It should be noted that according to the trial studies the statin-induced side-effects can occur relatively rarely, in approximately $1-5 \%$ of examined patients, by manifesting themselves as myalgia and liver enzyme level elevation, which are reversible and can vanish shortly after such treatment is discontinued [5]. At the same time, in practice, the incidence of side-effects may be much more frequent, since these trials do not include patients with statin intolerance in their medical history [6].

It is known that the European Atherosclerosis Society (EAS) in its guidelines focuses on statin-associated muscle symptoms (SAMS) [7], which are indeed the most frequently occurring side-effects, although this can lead to underestimation of the real number of patients with statin intolerance [8]. The Canadian working group in its updated consensus [9] proposes to distinguish complete and partial statin intolerance depending on intolerance to any individual statin in its initial dose or some particular types of statins in certain doses.

Statin-induced adverse effects on the liver are rarely observed but they can manifest themselves as asymptomatic elevation of serum transaminase level (0.5-2\% patients), hepatitis, cholestasis and acute liver failure $[9,10]$.

Such factors as Asian ethnicity and genetic polymorphisms related to statin metabolism contribute to the increased incidence of statin-induced side-effects [10, 11]. These factors are a good reason to initiate this study.

The aim of the research was to study possible effects of the CYP3A5 (6986A>G), CYP2C9 $(430 C>T), C Y P 2 C 9(1075 A>C)$, SLCO1B1 $(521 T>C)$ and $B C R P(A B C G 2,421 C>A)$ gene polymorphisms on simvastatin intolerance development in ethnic Uzbek patients with coronary artery disease (CAD).

\section{Material and methods}

The study was performed based on the case-control method in accordance with the protocol approved by the Local Ethics Committee of the Republican Specialised Centre of Cardiology. Before the study all enrolled patients provided informed consent. In the study, 100 patients with chronic CAD were enrolled based on the verified myocardial infarction diagnosed from their medical history, functional test and/or coronary angiography.

The case group included 50 patients with CAD who demonstrated simvastatin-induced adverse liver effects (transaminase level increases 3 times and more - in 37 cases) or SAMS with statin-induced elevations in serum creatine kinase (CK) (of $>3 \times U N L ~-~ i n ~ 13$ cases) at treatment with simvastatin with the dose of 10-20 mg/day for 3 months of treatment. The control group contained
50 patients with chronic CAD provided that these patients tolerated simvastatin therapy at doses of 20-40 mg and did not have side-effects for 1 year.

Patients who survived myocardial infarction (MI) within the previous 3 months, with atrial fibrillation, chronic heart failure higher than class II (NYHA), chronic renal and hepatic failures as well as those patients who had been diagnosed with an elevated transaminase level before admission were excluded from the study.

The basic therapy included: antiplatelets (100\%), $\beta$-blockers (bisoprolol, 100\%), if required, angiotensin convertase enzyme (ACE) inhibitors (90\%) and nitrates (60\%).

In order to estimate the clinical status, the following risk factors were studied: elevated arterial BP, smoking, body mass index, diabetes mellitus (DM); clinical and biochemical parameters: $12-$ lead ECG; 24-hour Holter ECG monitoring; exercise stress test; echocardiography (EchoCG); carotid artery intima-media thickness (IMT); coronary angiography.

The following blood lipid spectrum parameters were studied: total cholesterol (TC), low-density lipoprotein cholesterol (LDL-C), high-density lipoprotein cholesterol (HDL-C), triglycerides (TG), atherogenic index (AI), biochemical indicators (ALT, AST, CK) Daytona (Randox, Ireland). The atherogenic index (Al) was determined from the following expression: $\mathrm{Al}=(\mathrm{TC}-\mathrm{HDL}-\mathrm{C}) / \mathrm{HDL}-\mathrm{C}$ (relative units).

\section{Determination of genotypic frequencies}

Polymerase chain reaction-restriction fragment length polymorphism (PCR-RFLP) analysis was used to determine the genotypic frequencies of five polymorphisms. The primers and restriction endonucleases used for PCR-RFLP analysis are summarized in Table I [12-16].

\section{Statistical analysis}

The Statistica 6.0 advanced statistical analysis package was used for the statistical analysis of obtained data. The obtained data were presented as mean and standard deviation (mean \pm SD), where the statistical significance of the obtained measurements for compared mean values was determined by Student's $t$-test $(t)$ with calculated error probability $(P)$ to check normality of the distribution. If the distribution of studied variables differed from the normal distribution, the non-parametric Mann-Whitney T-test for two samples was used. In order to determine the difference between qualitative statistical measures, the $\chi^{2}$ method was used together with Fisher's exact test for small samples.

The empirical genotype frequency distribution conformance to the theoretically expected 
Table I. Primers used in the study

\begin{tabular}{|c|c|c|c|c|c|}
\hline Gene & Primer set & Position & Detection & Annealing $\left[{ }^{\circ} \mathrm{C}\right]$ & ${ }^{*}$ Refs. \\
\hline CYP $3 A 5^{*} 3$ & $\begin{array}{c}\text { F-5-CCTGCCTTCAATTTTCACT-3 } \\
\text { R-5-GGTCCAAACAGGGAAGAGGT-3 }\end{array}$ & $(6986 A>G)$ & $\begin{array}{l}\text { RFLP } \\
\text { Rsal }\end{array}$ & 61 & [12] \\
\hline $\mathrm{CYP} 2 \mathrm{C} 9^{*} 2$ & $\begin{array}{l}\text { 5'-ATCCACATGGCTGCCCAGTGTCA-3 } \\
\text { 5-CACATGAGCTAACAACCAGACTCA-3 }\end{array}$ & $(430 C>T)$ & $\begin{array}{c}\text { RFLP } \\
\text { Bme18I }\end{array}$ & 56 & [13] \\
\hline $\mathrm{CYP} 2 \mathrm{C} 9 * 3$ & $\begin{array}{c}\text { 5-TGCACGAGGTCCAGAGGTAC-3 } \\
\text { 5'-ACAAACTTACCTTGGGAATGAGA3 }\end{array}$ & $(1075 A>C)$ & $\begin{array}{l}\text { RFLP } \\
\text { Kpnl }\end{array}$ & 56 & [14] \\
\hline SLCO1B1 & $\begin{array}{c}\text { F-5-TTG TCA AAG AAG TTT GCA AAG TG-3 } \\
\text { R-5-GAA GCA TAT TAC CCA TGA GC-3 }\end{array}$ & $(521 \mathrm{~T}>\mathrm{C})$ & $\begin{array}{c}\text { RFLP } \\
\text { AspLE I }\end{array}$ & 56 & [15] \\
\hline $\begin{array}{l}\text { BCRP } \\
(A B C G 2)\end{array}$ & $\begin{array}{l}\text { F-5-TGTTGTGATGGGCACTCTGATG-3 } \\
\text { R-5-ATCAGAGTCATTTTATCCACAC -3 }\end{array}$ & $(421 C>A)$ & $\begin{array}{l}\text { RFLP } \\
\text { Bst4Cl }\end{array}$ & 56 & [16] \\
\hline
\end{tabular}

Table II. Baseline characteristics of examined patients

\begin{tabular}{|lcc|}
\hline Indicators & $\begin{array}{c}\text { Group I } \\
\text { (case) } \\
(N=50)\end{array}$ & $\begin{array}{c}\text { Group II } \\
\text { (control) } \\
(N=50)\end{array}$ \\
\hline Males & $21(42 \%)$ & $28(56 \%)$ \\
\hline Females & $29(58 \%)$ & $22(44 \%)$ \\
\hline Age & $59.3 \pm 10.4$ & $61.7 \pm 9.0$ \\
\hline Body mass index [kg/m²] & $28.2 \pm 3.1$ & $28.9 \pm 2.7$ \\
\hline CHD duration [years] & $5.0 \pm 3.2$ & $6.3 \pm 3.6$ \\
\hline $\begin{array}{l}\text { Myocardial infarction in } \\
\text { medical history }\end{array}$ & $8(16 \%)$ & $16(32 \%)$ \\
\hline Diabetes mellitus type 2 & $11(22 \%)$ & $16(32 \%)$ \\
\hline Therapy duration [months] & $3-12$ & $12-24$ \\
\hline $\begin{array}{l}\text { Simvastatin dose, median } \\
\text { (dose range) [mg/day] }\end{array}$ & $15(10-20)$ & $30(20-40)$ \\
\hline Total cholesterol (CS) [mg/dl] & $213.3 \pm 45.7$ & $205.1 \pm 35.5$ \\
\hline TG [mg/dl] & $159.8 \pm 67.4$ & $186.7 \pm 91.9$ \\
\hline LDL-C [mg/dl] & $136.6 \pm 40.1$ & $127.1 \pm 27.5$ \\
\hline HDL-C [mg/dl] & $43.1 \pm 12.7$ & $40.8 \pm 10.3$ \\
\hline VLDL-C [mg/dl] & $31.9 \pm 13.4$ & $37.6 \pm 18.2$ \\
\hline Al [relative units] & $4.2 \pm 1.3$ & $4.3 \pm 1.2$ \\
\hline
\end{tabular}

Hardy-Weinberg equilibrium was checked by the $\chi^{2}$ test.

In order to compare favourable and unfavourable outcome frequencies in independent groups of events the odds ratios (OR) were calculated by determining the $95 \%$ confidence interval $(\mathrm{Cl})$. Differences in the studied binary characteristics were considered to be statistically significant if $\mathrm{Cl}$ for the OR did not include 1. The confidence level of $p<0.05$ was accepted to be statistically significant.

\section{Results}

There was no difference between baseline levels in examined patients from groups I (case) and II (control) (Table II).
The objectives of this study allowed enrolment of patients with simvastatin intolerance in the medical history that partially explained the proportion of patients detected with adverse hepatic effects. However, the starting drug dose in these patients was $10 \mathrm{mg} /$ day, whereas in the rest of the patients it was $20 \mathrm{mg} /$ day, which was increased to $40 \mathrm{mg} /$ day if intolerance was not manifested. Intolerance was considered to be the development of the above-mentioned clinical symptoms accompanied by changes in biochemical indicators induced by simvastatin doses of $10-20 \mathrm{mg} /$ day. Therefore, the median simvastatin dose in the case group was half that in the control group.

In all cases, the studied genotypes frequency in patients ( $n=100$ ) corresponded to the HardyWeinberg equilibrium (Table III), apart from the CYP2C9*2 distribution, which was in disequilibrium $(p<0.001)$ for ethnic Uzbek patients with CAD.

Comparing prevalence of the most frequent homozygous genotypes with that of variant genotypes (Table III) demonstrated that in the case group the CYP3A5 gene ${ }^{*} 3{ }^{*} 3$ genotype $(p=$ $0.0001)$ and the variant genotype CA BCRP gene ( $p=0.024)$ were predominant. This may be due to an increased content of the lactone of simvastatin in the liver $\left(\mathrm{CYP} 3 A 5^{*} 3 /^{*} 3\right)$, and the fact that increased discharge of lipophilic simvastatin lactone in bile (BCRP CA) may cause in some susceptible patients passive diffusion of the drug through the damaged epithelium of the bile ducts.

When 37 patients with simvastatin-induced liver effects were compared with the control group, the ${ }^{*} 3 /{ }^{*} 3$ genotype of the CYP3A5 gene $(p=0.0001)$ and variant genotype of the CA BCRP gene $(p=0.0001)$ were also observed more frequently (Table IV).

However, when the 13 patients who had SAMS were compared with the control group $(n=50)$, it was found that in the case group the genotype $3^{*} / 3^{*}$ CYP3A5 gene $(p=0.003)$ and $C$ allele SLCO1B1 gene polymorphism carriers $(p=0.017)$ were predominant (Table V). 
Table III. Distribution of polymorphic gene markers of studied genotypes in case and control groups

\begin{tabular}{|c|c|c|c|c|}
\hline Genotypes & & $\begin{array}{c}\text { Group I (case) } \\
N=50\end{array}$ & $\begin{array}{c}\text { Group II (control) } \\
\qquad N=50\end{array}$ & Significance \\
\hline \multirow[t]{2}{*}{ CYP3A5 } & ${ }^{*} 3 / * 3$ & 28 & 6 & \multirow{2}{*}{$\begin{array}{c}\mathrm{OR}=9.33 \\
95 \% \mathrm{Cl}: 3.37-25.9 \\
\chi^{2}=19.7 ; p<0.001\end{array}$} \\
\hline & $\begin{array}{c}{ }^{*} 1 \text { carriers: } \\
{ }^{*} 1{ }^{*} 3 \text { and }{ }^{*} 1{ }^{*} 1\end{array}$ & 22 & 44 & \\
\hline \multirow[t]{2}{*}{$\mathrm{CYP} 2 \mathrm{C9}^{*} 2$} & ${ }^{*} 1 /{ }^{*} 1$ & 40 & 39 & \multirow{2}{*}{$\begin{array}{c}\mathrm{OR}=1.13 \\
95 \% \mathrm{Cl}: 0.43-2.96 \\
\chi^{2}=0.00 ; p=1.00\end{array}$} \\
\hline & $\begin{array}{c}\text { Variants } \\
{ }^{*} 2 \text { carriers: } \\
{ }^{*} 1 /{ }^{*} 2 \text { and }{ }^{*} 2 /{ }^{*} 2\end{array}$ & 10 & 11 & \\
\hline \multirow[t]{2}{*}{$\mathrm{CYP} 2 \mathrm{C}^{*} 3$} & ${ }^{\star} 1 /{ }^{\star} 1$ & 40 & 42 & \multirow{2}{*}{$\begin{array}{c}\mathrm{OR}=0.76 \\
95 \% \mathrm{Cl}: \\
0.27-2.13 \\
\chi^{2}=0.07 ; p=0.80\end{array}$} \\
\hline & $\begin{array}{c}* 3 \text { carriers: } \\
{ }^{*} 1 /{ }^{*} 3\left(\text { no } * 3 /{ }^{*} 3\right)\end{array}$ & 10 & 8 & \\
\hline \multirow[t]{2}{*}{ BCRP } & $\begin{array}{l}\text { C carriers: } \\
\text { CA (no CC) }\end{array}$ & 19 & 8 & \multirow{2}{*}{$\begin{array}{c}\mathrm{OR}=3.22 \\
95 \% \mathrm{Cl}: \\
1.25-8.30 \\
\chi^{2}=5.07 ; p=0.024\end{array}$} \\
\hline & AA & 31 & 42 & \\
\hline \multirow[t]{2}{*}{ SLCO1B1 } & $\mathrm{TT}$ & 35 & 36 & \multirow{2}{*}{$\begin{array}{c}\mathrm{OR}=0.91 \\
95 \% \mathrm{Cl}: \\
0.38-2.15 \\
\chi^{2}=0.000 ; p=1.00\end{array}$} \\
\hline & $\begin{array}{c}\text { C carriers } \\
\text { TC, CC }\end{array}$ & $15^{\wedge}$ & $14^{\wedge \wedge}$ & \\
\hline
\end{tabular}

$\wedge 2$ with CC genotype; ${ }^{\wedge} 1$ with CC genotype.

Table IV. Distribution of polymorphic gene markers of studied genotypes in patients with hepatic side-effects in case and control groups $(1: 1.35)$

\begin{tabular}{|c|c|c|c|c|}
\hline Genotypes & & $\begin{array}{c}\text { Group I (case) } \\
N=37\end{array}$ & $\begin{array}{c}\text { Group II (control) } \\
N=50\end{array}$ & Significance \\
\hline \multirow[t]{2}{*}{ CYP3A5 } & $* 3 / * 3$ & 21 & 6 & \multirow{2}{*}{$\begin{array}{c}\mathrm{OR}=9.63 \\
95 \% \mathrm{Cl}: \\
3.29-28.1 \\
\chi^{2}=17.9 ; p<0.001\end{array}$} \\
\hline & $\begin{array}{c}{ }^{*} 1 \text { carriers: } \\
{ }^{*} 1 /{ }^{*} 3 \text { and }{ }^{*} 1 /{ }^{*} 1\end{array}$ & 16 & 44 & \\
\hline \multirow[t]{2}{*}{$\mathrm{CYP} 2 \mathrm{CP}^{*} 2$} & ${ }^{*} 1 /{ }^{*} 1$ & 31 & 39 & \multirow{2}{*}{$\begin{array}{c}\mathrm{OR}=1.46 \\
95 \% \mathrm{Cl}: \\
0.49-4.38 \\
\chi^{2}=0.16 ; p=0.69\end{array}$} \\
\hline & $\begin{array}{c}\text { Variants } \\
{ }^{*} 2 \text { carriers: } \\
{ }^{*} 1 /{ }^{*} 2 \text { and }{ }^{*} 2 /{ }^{*} 2\end{array}$ & 6 & 11 & \\
\hline \multirow[t]{2}{*}{$\mathrm{CYP} 2 \mathrm{C}^{*} 3$} & ${ }^{*} 1 /{ }^{*} 1$ & 30 & 42 & \multirow{2}{*}{$\begin{array}{c}\mathrm{OR}=0.82 \\
95 \% \mathrm{Cl}: \\
0.27-2.50 \\
\chi^{2}=0.005 ; p=0.95\end{array}$} \\
\hline & $\begin{array}{c}\text { *3 carriers: } \\
{ }^{*} 1 /{ }^{*} 3\left(\text { no * } 3 /{ }^{*} 3\right)\end{array}$ & 7 & 8 & \\
\hline \multirow[t]{2}{*}{ BCRP } & $\begin{array}{l}\text { C carriers: } \\
\text { CA (no CC) }\end{array}$ & 22 & 8 & \multirow{2}{*}{$\begin{array}{c}\mathrm{OR}=7.7 \\
95 \% \mathrm{Cl}: \\
2.83-20.9 \\
\chi^{2}=15.9 ; p<0.001\end{array}$} \\
\hline & $\mathrm{AA}$ & 15 & 42 & \\
\hline \multirow[t]{2}{*}{ SLCO1B1 } & TT & 30 & 36 & \multirow{2}{*}{$\begin{array}{c}\mathrm{OR}=1.67 \\
95 \% \mathrm{Cl}: \\
0.60-4.66 \\
\chi^{2}=0.53 ; p=0.47\end{array}$} \\
\hline & $\begin{array}{c}\text { C carriers } \\
\text { TC, CC }\end{array}$ & $7^{\wedge}$ & $14^{\wedge \wedge}$ & \\
\hline
\end{tabular}

${ }^{\wedge}$ No with CC genotype; ${ }^{\wedge} 1$ with CC genotype.

\section{Discussion}

In our study, the genotypes * $3{ }^{*} 3$ CYP3A5 and CA BCRP were observed with a high level of confidence in patients with simvastatin intolerance. It is well documented that simvastatin is extensively metabolized by both CYP3A4 and CYP3A5.

Since the ${ }^{*} 3$ allele expression is accompanied by CYP3A5 activity decrease, this can contribute to the statin-associated concentration increase in blood plasma. In the Kim et al. [17] study, a group of healthy Korean volunteer carriers of the CYP3A5 * $3{ }^{*} 3$ genotype demonstrated a much higher (3.3 times higher) 12-hour simvastatin exposure in blood, which was also supported by another study covering African-Americans [18], although it was not observed in Caucasians. Also, in a number of 
Table V. Distribution of polymorphic gene markers of studied genotypes in patients with muscular side-effects in case and control groups $(1: 3.85)$

\begin{tabular}{|c|c|c|c|c|}
\hline Genotypes & & $\begin{array}{c}\text { Group I (case) } \\
N=13\end{array}$ & $\begin{array}{c}\text { Group II (control) } \\
\quad N=50\end{array}$ & Significance \\
\hline \multirow[t]{2}{*}{ CYP3A5 } & ${ }^{*} 3 / * 3$ & 7 & 6 & \multirow{2}{*}{$\begin{array}{c}\mathrm{OR}=8.56 \\
95 \% \mathrm{Cl}: \\
2.14-34.1 \\
\chi^{2}=8.63 ; p=0.003\end{array}$} \\
\hline & $\begin{array}{c}\text { * } 1 \text { carriers: } \\
{ }^{*} 1 /{ }^{*} 3 \text { and }{ }^{*} 1 /{ }^{*} 1\end{array}$ & 6 & 44 & \\
\hline \multirow[t]{2}{*}{$\mathrm{CYP} 2 \mathrm{CP}^{*} 2$} & ${ }^{*} 1 /{ }^{*} 1$ & 9 & 39 & \multirow{2}{*}{$\begin{array}{c}\mathrm{OR}=0.64 \\
95 \% \mathrm{Cl}: \\
0.16-2.46 \\
\chi^{2}=0.88 ; p=0.77\end{array}$} \\
\hline & $\begin{array}{c}\text { Variants } \\
\text { *2 carriers: } \\
{ }^{*} 1 /{ }^{*} 2 \text { and }{ }^{*} 2 /{ }^{*} 2\end{array}$ & 4 & 11 & \\
\hline \multirow[t]{2}{*}{$\mathrm{CYP} 2 \mathrm{CP}^{*} 3$} & ${ }^{*} 1 /{ }^{*} 1$ & 10 & 42 & \multirow{2}{*}{$\begin{array}{c}\mathrm{OR}=0.64 \\
95 \% \mathrm{Cl}: \\
0.14-2.83 \\
\chi^{2}=0.036 ; p=0.85\end{array}$} \\
\hline & $\begin{array}{c}* 3 \text { carriers: } \\
{ }^{*} 1 /{ }^{*} 3\left(\text { no } * 3 /{ }^{*} 3\right)\end{array}$ & 3 & 8 & \\
\hline \multirow[t]{2}{*}{ BCRP } & $\begin{array}{l}\text { C carriers: } \\
\text { CA (no CC) }\end{array}$ & 4 & 8 & \multirow{2}{*}{$\begin{array}{c}\mathrm{OR}=2.33 \\
95 \% \mathrm{Cl}: \\
0.58-9.46 \\
\chi^{2}=0.66 ; p=0.42\end{array}$} \\
\hline & AA & 9 & 42 & \\
\hline \multirow[t]{2}{*}{ SLCO1B1 } & $\begin{array}{c}\text { C carriers } \\
\text { TC, CC }\end{array}$ & $8^{\wedge}$ & $14^{\wedge} \wedge$ & \multirow{2}{*}{$\begin{array}{c}\mathrm{OR}=4.11 \\
95 \% \mathrm{Cl}: \\
1.15-14.8 \\
\chi^{2}=3.74 ; p=0.05\end{array}$} \\
\hline & $\mathrm{TT}$ & 5 & 36 & \\
\hline \multirow{2}{*}{$\begin{array}{l}\text { SLCO1B1 } \\
\text { alleles }\end{array}$} & $C$ alleles & 10 & 15 & \multirow{2}{*}{$\begin{array}{c}\mathrm{OR}=3.54 \\
95 \% \mathrm{Cl}: \\
1.35-9.27 \\
\chi^{2}=5.7 ; p=0.017\end{array}$} \\
\hline & T alleles & 16 & 85 & \\
\hline
\end{tabular}

studies a correlation was found between carriage of the CYP $3 A 5^{*} 3 * 3$ genotype and much higher lipid-lowering efficacy of the simvastatin treatment in Caucasian and Chinese patients [19-21].

At the same time, Fiegenbaum et al. did not discover any simvastatin-associated efficacy or intolerance in $\mathrm{CYP} 3 \mathrm{~A} 55^{*} 3$ carriers [22].

In other studies, the relation between cholesterol level lowering effect and carriage of the CYP3A4 22 allele was demonstrated mainly for Caucasian ancestry patients [23], which was supported by the experimental data obtained in trials $[24,25]$.

Thus, the simvastatin metabolism combined effects caused by the CYP3A4 and functional CYP3A5 activities; existence of such dual combination partially impairs clinical effects of the CYP3A5 genetic polymorphism, but in case of its insufficiency a higher total activity of the CYP3A, particularly a more significant role of CYP3A4, is required in subjects [26-29]. By combining CYP3A4*22 with CYP 3 A 5 alleles ${ }^{*} 1,{ }^{*} 3$ and ${ }^{*} 7$ one can obtain a promising biomarker allowing prediction of overall CYP3A activity.

It is known that $85 \%$ of Caucasian subjects do not express functionally full CYP3A5. However, lack of functional CYP3A5 can be substituted in them by the metabolism taking place via the universally expressed CYP3A4 [26, 27], which may apparently be a compensatory mechanism developed during evolution. This could explain differences in the simvastatin effect in Asians [17, 21] and African-Americans [18], in whom CYP3A5 plays a crucial role in total metabolism because of its high prevalence.

On one hand, the simvastatin-induced adverse muscular side effects observed in this study in the genotype $\mathrm{CYP} 3 \mathrm{~A} 5^{*} 3^{*} 3$ carrier ethnic Uzbeks can be explained by the increase of its lactone form exposure in blood plasma [17]. On the other hand, it is known that the solute protein-transporter gene SLCO1B1 (c.521T>C) single nucleotide polymorphism reduces transport activity of OATP1B1 that reduces hepatic uptake of acid form of simvastatin, which is accompanied by elevation of its concentration in blood plasma and increases myopathy risk at high doses of simvastatin [28, 29]. For the first time, in the large-scale SEARCH study, an association was established between gene polymorphism of the SLCO1B1 (c.521T>C) solute transporter and statin-induced myopathy development in those patients who were given simvastatin doses of $80 \mathrm{mg} /$ day for C-allele carriers [29].

However, in the study presented in this paper, in the case group along with 13 SAMS cases, the reason for therapy discontinuation in 37 examined patients was simvastatin-induced effects on liver. These effects in ethnic Uzbek patients with 
*3*3 CYP3A5 genotype could be to some extent explained by simvastatin lactone exposure increase in the liver as a result of passive diffusion across the cell membrane of hepatocytes and inhibition of its conversion into acid, which was related to the lack of CYP3A5 expression and low functional activity of CYP3A4.

Statins are excretion transporter substrates including ATP-binding cassette transporter BCRP $(A B C G 2)$. By localizing predominantly on the apical membrane of the small intestinal epithelium and hepatocyte canalicular membrane, BCRP can restrict intestinal absorption or increase elimination of its substrates from the liver to the bile, limiting their systemic and organ exposure [30, 31].

One of the most studied BCRP polymorphisms, $421 C>A$, is related to reduction of the transport activity in in vitro studies [32, 33]. According to the published data, prevalence of the A allele is 10-15\% in Caucasian, 25-35\% in Asian and 0-5\% in African-American and African subjects [34, 35].

However, these figures were subject to variation in clinical studies. For example, the A allele frequency reaches $46 \%$ in the Japanese population [36] and $58.6 \%$ in Chinese subjects living in the USA [11]. It is of special interest to mention the study in which for the first time the BCRP allele prevalence was investigated in a Turkish population [37], where AA genotype carrier frequency in 157 healthy subjects was $98.7 \%$, whereas that in 108 patients was $72.2 \%$, which coincided with our results $-73.0 \%$ in ethnic Uzbeks.

The patients with homozygous BCRP 421A/A genotype had elevated levels of rosuvastatin and atorvastatin in their blood plasma [34, 38], which was related to a decrease in the drugs' efflux to the canalicular bile.

In the classical study of Keskitalo et al. [39] it was demonstrated that in the subjects with BCRP polymorphism AA C421>A genotype the simvastatin lactone concentration changed significantly, whereas the simvastatin acid concentration in blood remained almost the same, which resulted in the acid/lactone ratio being larger by $46 \%$ ( $p<$ $0.05)$ with statistical significance among $C$ allele carriers. However, in the mentioned classical study [39], in order to eliminate a potential mixture of genetic factors, patient carriers of the ${ }^{*} 3$ allele CYP3A5 were excluded.

It is known that the difference between rosuvastatin and simvastatin is that the latter, being a lipophilic prodrug, can autonomously enter through the hepatocyte membrane to transform into the active acid form inside the cell. In the $C$ allele carriers' liver, the role of the BCRP gene C421>A polymorphism is to efflux simvastatin lactone (as well as rosuvastatin) from tissue to canalicular bile. However, possible consequences of such efflux can be significantly different for hydrophilic rosuvastatin and lipophilic simvastatin. Furthermore, there is speculation as to whether bile ductular reabsorption of bile salts and lipophilic drugs and cholehepatic shunting could result in changes in bile composition and promote hepatic drug accumulation [40], which in a most interesting way is demonstrated based on the experimental trials with troglitazone toxicity [41, 42]. Capabilities of the nonsteroidal anti-inflammatory drug sulindac to induce hypercholeresis in rats - a phenomenon that is explained by cholehepatic shunting - have been described [43].

It is conceivable that drug reabsorption by cholangiocytes and cholehepatic shunting contributes to the development of hepatic damage. It is quite well known in cardiology that ursodeoxycholic acid and some new agents [44] contribute to elimination of cholehepatic shunting and decrease of statin-induced side effects.

Thus, in patients with combined ${ }^{*} 3 /{ }^{*} 3$ genotype (6986A>G) CYP3A5 and CA (421C>A) BCRP along with a threefold simvastatin concentration elevation in blood plasma [21], simvastatin efflux to bile through the canalicular membrane takes place. However, in contrast to the hydrophilic rosuvastatin, increased efflux of lipophilic simvastatin to bile may be accompanied by bile ductular reabsorption of bile salts and drugs, and cholehepatic shunting could result in changes in bile composition and promote toxic effects as a result of hepatic drug accumulation.

It is also known that many other factors including age, ethnicity, accompanying diseases and administered drugs can cause significant effects on individual characteristics of statin pharmacokinetics.

The obvious limitation of this study, with hindsight, is the method for gathering data, based on the selection of a case group of patients with simvastatin intolerance, whereas this phenomenon is not uniform.

Future studies should be planned concentrating on one of the intolerance phenomena: simvastatin-associated muscle (SAMS) or liver symptoms, which will allow more careful analysis of results to be carried out. However, as it seems to us, there was one advantage in the chosen approach: the ability to compare two phenomena and to outline a difference of the genetic determinants, having found out that not only an increase of the statins' concentration in the blood is the basis for the development of adverse symptoms.

In conclusion, the ${ }^{*} 3 /{ }^{*} 3$ genotype of the CYP3A5 $(6986 A>G)$ gene and CA genotype of the $B C R P(A B C G 2,421 C>A)$ gene were associated with the simvastatin-induced liver symptoms in ethnic Uzbek CAD patients, whereas in patients with simvastatin-associated muscle symptoms (SAMS), 
the combination of $* 3 / * 3$ genotype of the CYP3A5 $(6986 \mathrm{~A}>\mathrm{G})$ gene and carriage of the $C$ allele of the SLCO1B1 gene polymorphism was predominant.

\section{Acknowledgments}

This work was supported by a research grant from the Ministry of Health and State Uzbek scientific committee.

\section{Conflict of interest}

The authors declare no conflict of interest.

\section{References}

1. Reiner Z, Catapano AL, De Backer G, et al. ESC/EAS guidelines for the management of dyslipidaemias: the Task Force for the management of dyslipidaemias of the European Society of Cardiology (ESC) and the European Atherosclerosis Society (EAS). Eur Heart J 2011; 32: 1769-818.

2. Baigent C, Keech A, Kearney PM, et al.; Cholesterol Treatment Trialists' (CTT) Collaborators. Efficacy and safety of cholesterol-lowering treatment: prospective meta-analysis of data from 90,056 participants in 14 randomised trials of statins. Lancet 2005; 366: 1267-78.

3. Hague WE, Simes J, Kirby A, et al. Long-term effectiveness and safety of pravastatin in patients with coronary heart disease: sixteen years of follow-up of the LIPID study. Circulation 2016; 133: 1851-60.

4. Ford ES, Ajani UA, Croft JB, et al. Explaining the decrease in U.S. deaths from coronary disease, 1980-2000. N Engl J Med 2007; 356: 2388-98.

5. Bays H. Statin safety: an overview and assessment of the data-2005. Am J Cardiol 2006; 97: 6C-26C.

6. Maningat P, Breslow JL. Needed: pragmatic clinical trials for statin-intolerant patients N Engl J Med 201; 365 : 2250-1.

7. Stroes ES, Thompson PD, Corsini A, et al.; European Atherosclerosis Society Consensus Panel. Statin-associated muscle symptoms: impact on statin therapy - European Atherosclerosis Society Consensus Panel Statement on Assessment, Aetiology and Management. Eur Heart J 2015; 36: 1012-22.

8. Thompson PD, Clarkson P, Karas RH. Statin-associated myopathy. JAMA 2003; 289: 1681-90.

9. Mancini GB, Tashakkor AY, Baker S, et al. Diagnosis, prevention, and management of statin adverse effects and intolerance: Canadian Working Group Consensus update. Can J Cardiol 2013; 29: 1553-68.

10. Banach M, Rizzo M, Toth P, et al. Statin intolerance - an attempt at a unified definition. Position paper from an International Lipid Expert Panel. Arch Med Sci 2015; 11: $1-23$.

11. Birmingham BK, Bujac SR, Elsby R, et al. Impact of $A B C G 2$ and SLCO1B1 polymorphisms on pharmacokinetics of rosuvastatin, atorvastatin and simvastatin acid in Caucasian and Asian subjects: a class effect? Eur J Clin Pharmacol 2015; 71: 341-55.

12. Maruf AA, Ahmed MU, Yasmin H, et al. Genotypes and phenotypes of CYP3A in Bangladeshi population, Clin Chim Acta 2011; 412: 531-6.

13. Wang SL, Huang J, Lai MD, Tsai JJ. Detection of CYP2C9 polymorphism based on the polymerase chain reaction in Chinese. Pharmacogenetics 1995; 5: 37-42.
14. Sullivan-Klose TH, Ghanayem BI, Bell DA, et al. The role of the CYP2C9-Leu359 allelic variant in the tolbutamide polymorphism. Pharmacogenetics 1996; 6: 341-9.

15. Liu J, Long J, Shaofang Z, Xiaoyan F, Yuyuan L. Polymorphic variants of SLCO1B1 in neonatal hyperbilirubinemia in China. Ital J Pediatr 2013; 39: 49.

16. Meissner K, Heydrich B, Jedlitschky G, et al. The ATP-binding cassette transporter ABCG2 (BCRP), a marker for side population stem cells, is expressed in human heart. J Histochem Cytochem 2006; 54: 215-21.

17. Kim KA, Park PW, Lee OJ, Kang DK, Park JY. Effect of polymorphic CYP3A5 genotype on the single-dose simvastatin pharmacokinetics in healthy subjects. J Clin Pharmacol 2007; 47: 87-93.

18. Kitzmiller JP, Luzum JA, Baldassarre D, Krauss RM, Medina MW. CYP3A4*22 and CYP3A5*3 are associated with increased levels of plasma simvastatin concentrations in the cholesterol and pharmacogenetics study cohort. Pharmacogenet Genom 2014; 24: 486-91.

19. Kolovou G, Ragia G, Kolovou V, et al. Impact of CYP3A5 gene polymorphism on efficacy of simvastatin. Open Cardiovasc Med J 2014; 8: 12-7.

20. Kivistö KT, Niemi M, Schaeffeler E, et al. Lipid-lowering response to statins is affected by CYP3A5 polymorphism. Pharmacogenetics 2004; 14: 523-5.

21. Li YP, Zhang LR, Jia M, Hu XJ. CYP3AP1*3 allele is associated with lipid-lowering efficacy of simvastatin and atorvastatin in Chinese women. J Clin Pharmacol 2011; 51: 181-8.

22. Fiegenbaum M, da Silveira FR, Van der Sand CR, et al. The role of common variants of ABCB1, CYP3A4, and CYP3A5 genes in lipid-lowering efficacy and safety of simvastatin treatment. Clin Pharmacol Ther 2005; 78 : 551-8.

23. Elens L, Becker ML, Haufroid V, et al. Novel CYP3A4 intron 6 single nucleotide polymorphism is associated with simvastatin-mediated cholesterol reduction in the Rotterdam study. Pharmacogenet Genom 2011; 21 861-6.

24. Wang D, Guo Y, Wrighton SA, Cooke GE, Sadee W. Intronic polymorphism in CYP3A4 affects hepatic expression and response to statin drugs. Pharmacogenom J 2011; 11: 274-86.

25. Sata F, Sapone A, Elizondo G, et al. CYP3A4 allelic variants with amino acid substitutions in exons 7 and 12 : evidence for an allelic variant with altered catalytic activity. Clin Pharmacol Ther 2000; 67: 48-56.

26. Evans WE, McLeod HL. Pharmacogenomics - drug disposition, drug targets, and side effects. N Engl J Med 2003; 348: 538-49.

27. Wang D, Sadee WJ. The making of a CYP3A biomarker panel for guiding drug therapy. Pers Med 2012; 2: 175-91.

28. Pasanen MK, Neuvonen M, Neuvonen PJ, Niemi $M$. SLCO1B1 polymorphism markedly affects the pharmacokinetics of simvastatin acid. Pharmacogenet Genom 2006; 16: 873-9.

29. Link E, Parish S, Armitage J, et al. SLCO1B1 variants and statin-induced myopathy - a genomewide study. N Engl J Med 2008; 359: 789-99.

30. Niemi M. Transporter pharmacogenetics and statin toxicity. Clin Pharmacol Ther 2010; 87: 130-3.

31. Lee CA, O'Connor MA, Ritchie TK, et al. Breast cancer resistance protein $(A B C G 2)$ in clinical pharmacokinetics and drug interactions: practical recommendations for clinical victim and perpetrator drug-drug interaction study design. Drug Metab Dispos 2015; 43: 490-509. 
32. Kondo $\mathrm{C}$, Suzuki $\mathrm{H}$, Itoda $\mathrm{M}$, et al. Functional analysis of SNPs variants of BCRP/ABCG2. Pharm Res 2004; 21: 1895-903.

33. Morisaki K, Robey RW, Ozvegy-Laczka C, et al. Single nucleotide polymorphisms modify the transporter activity of ABCG2. Cancer Chemother Pharmacol 2005; 56: 161-72.

34. Keskitalo JE, Zolk O, Fromm MF, Kurkinen KJ, Neuvonen PJ, Niemi M. ABCG2 polymorphism markedly affects the pharmacokinetics of atorvastatin and rosuvastatin. Clin Pharmacol Ther 2009; 86: 197-203.

35. Robey RW, To KKK, Polgar O, Dohse M, Fetsch P, Dean M, Bates SE. ABCG2: a perspective. Adv Drug Deliv Rev 2009; 61: 3-13.

36. Imai Y, Nakane M, Kage K, et al. C421A polymorphism in the human breast cancer resistance protein gene is associated with low expression of Q141K protein and low-level drug resistance. Mol Cancer Ther 2002; 1: 611-6.

37. Sari FM, Yanar HT, Ozhan G. Investigation of the functional single-nucleotide polymorphisms in the BCRP transporter and susceptibility to colorectal cancer. Biomed Rep 2015; 3: 105-9.

38. Zhang W, Yu BN, He YJ, et al. Role of BCRP 421C_A polymorphism on rosuvastatin pharmacokinetics in healthy Chinese males. Clin Chim Acta 2006; 373: 99-103.

39. Keskitalo JE, Pasanen MK, Neuvonen PJ, Niemi M. Different effects of the ABCG2 c.421C>A SNP on the pharmacokinetics of fluvastatin, pravastatin and simvastatin. Pharmacogenomics 2009; 10: 1617-24.

40. Pauli-Magnus C, Meier PJ. Hepatobiliary transporters and drug-induced cholestasis. Hepatology 2006; 44 778-87.

41. Enokizono J, Kusuhara H, Sugiyama Y. Involvement of breast cancer resistance protein (BCRP/ABCG2) in the biliary excretion and intestinal efflux of troglitazone sulfate, the major metabolite of troglitazone with a cholestatic effect. Drug Metabol Disposition 2007; 35: 209-14.

42. Pauli-Magnus C, Stieger B, Meier Y, Kullak-Ublick GA, Meier PJ. Enterohepatic transport of bile salts and genetics of cholestasis. J Hepatol 2005; 43: 342-57.

43. Bolder U, Trang NV, Hagey LR, et al. Sulindac is excreted into bile by a canalicular bile salt pump and undergoes a cholehepatic circulation in rats. Gastroenterology 1999; 117: 962-71.

44. Beuers U, Trauner M, Jansen P, Poupon R. New paradigms in the treatment of hepatic cholestasis: from UDCA to FXR, PXR and beyond. J Hepatol 2015; 62: 25-37. 